\title{
Article \\ Seedling Growth and Biomass Production under Different Light Availability Levels and Competition Types
}

\author{
Ieva Bebre ${ }^{1, *}$, Hannes Riebl $^{2}\left(\mathbb{D}\right.$ and Peter Annighöfer ${ }^{3}$ \\ 1 Silviculture and Forest Ecology of the Temperate Zones, University of Göttingen, Büsgenweg 1, \\ 37077 Göttingen, Germany \\ 2 Chair of Statistics, University of Göttingen, Humboldtallee 3, 37073 Göttingen, Germany; \\ hriebl@uni-goettingen.de \\ 3 Forest and Agroforest Systems, Technical University of Munich (TUM), Hans-Carl-von-Carlowitz-Platz 2, \\ 85354 Freising, Germany; peter.annighoefer@tum.de \\ * Correspondence: ieva.bebre@uni-goettingen.de
}

Citation: Bebre, I.; Riebl, H.; Annighöfer, P. Seedling Growth and Biomass Production under Different Light Availability Levels and Competition Types. Forests 2021, 12 1376. https://doi.org/10.3390/ f12101376

Academic Editor: Adele Muscolo

Received: 16 August 2021

Accepted: 5 October 2021

Published: 9 October 2021

Publisher's Note: MDPI stays neutral with regard to jurisdictional claims in published maps and institutional affiliations.

Copyright: (C) 2021 by the authors. Licensee MDPI, Basel, Switzerland. This article is an open access article distributed under the terms and conditions of the Creative Commons Attribution (CC BY) license (https:// creativecommons.org/licenses/by/ $4.0 /)$.
Abstract: Light availability is a crucial resource determining seedling survival, establishment, and growth. Competition for light is asymmetric, giving the taller individuals a competitive advantage for obtaining light resources. Species-specific traits, e.g., shade tolerance, rooting depth, and leaf morphology, determine their strategical growth response under limited resource availability and different competitive interactions. We established a controlled pot experiment using European beech, Norway spruce, and Douglas fir seedlings and applying three different light availability levels- $10 \%, 20 \%$, and $50 \%$. The experiment's main aim was to better understand the effects of light availability and competition type on the growth, growth allocation, and biomass production of recently planted seedlings. We planted four seedlings per pot in either monocultures or mixtures of two species. Relative height and diameter growth and aboveground woody biomass of seedlings increased with increasing light availability. All seedlings allocated more growth to height than diameter with decreasing light availability. Seedlings that reached on average greater height in the previous year allocated less growth to height in the following year. Additionally, there were general differences in growth allocation to the height between gymnosperms and angiosperms, but we did not find an effect of the competitor's identity. Our mixture effect analysis trends suggested that mixtures of functionally dissimilar species are more likely to produce higher biomass than mixtures of more similar species such as the two studied conifers. This finding points towards increased productivity through complementarity.

Keywords: shade tolerance; growth allocation; mixture effect; competition; pot experiment

\section{Introduction}

Light is one of the most crucial resources determining seedling survival, establishment, and growth $[1,2]$. Stem height and diameter determine tree size and, consequently, an individual's performance in given conditions [3]. Since competition for light resources is asymmetric, i.e., size-dependent, a taller individual has a competitive advantage over its smaller neighbors, which is particularly important during the seedling establishment and recruitment stages $[4,5]$. Overtopping the neighbors to seize the available light resource, thus hindering competing vegetation growth, is a typical example of a competitive growth strategy under size-asymmetric competition [6].

Seedlings growing under high light availability are generally larger and produce more biomass than seedlings receiving less light, regardless of species identity and characteristics $[7,8]$. However, the stress rate caused by limited light availability on seedling growth can depend on species-specific factors such as shade tolerance, plasticity, the competitive situation, and the general availability of resources $[9,10]$. 
Light-demanding species have a high competitive ability under open field conditions, where they can quickly capture light and overgrow more shade-tolerant species [11]. Lightdemanding species generally react stronger to increasing light availability due to more substantial stress relief, as well as allocate large shares of the photosynthetic by-products to height growth rather than diameter growth in low light conditions to maintain contact with the light source, even if that presents a growth-survival trade-off [12-14]. On the other hand, shade-tolerant species are more adapted to low-light habitats and can use the available light more efficiently $[15,16]$. This is possible via higher morphological plasticity on the leafand crown-level, allowing trees to, e.g., capture light through horizontal expansion [17].

Aboveground allometry of height versus diameter growth determines a plant's performance and reveals a trade-off between a plant's ability to compete with neighbors (gained through height increment) and the mechanical and physiological support (attained by diameter growth) $[3,18,19]$. Differences between angiosperms and gymnosperms, species' shade tolerance, competition for resources, and neighbor effects can all alter seedling allometry $[20,21]$. Gymnosperm tree species generally have higher diameter growth per unit of stem growth than angiosperms [3,22]. Light-demanding species often risk the stability over the potential of reaching a light source, and because of this growth strategy, fewer resources get allocated to diameter growth [23]. Additionally, the neighbor effect can influence seedling allometry through reduced competition. For example, when species of different shade tolerance are growing together, and the interspecific competition for light is lower than in monospecific stands, seedlings can use light more efficiently and do not have to sacrifice their stability (i.e., diameter growth) as much [21].

The strength of intraspecific versus interspecific competition largely depends on the species niche complementarity or similarity and self-tolerance [24]. When the growing conditions in a mixed stand facilitate higher biomass production than in monospecific stands, we assume positive mixing effects, i.e., overyielding [25,26]. For example, due to its high shade tolerance and low self-tolerance, European beech (Fagus sylvatica L.) generally benefits from admixtures of other species $[27,28]$. In comparison, the more light-demanding Douglas fir (Pseudotsuga menziesii (Mirb.) Franco) excels in mixtures with species that would not overgrow them in the early establishment stages and have high enough shade tolerance to deal with the vigorous growth after the seedlings have established $[21,29,30]$.

The next generation of trees often has to regenerate under older generations' cover [31]. To ensure a species mixture of shade-tolerant and light-demanding species, one must provide sufficient light availability for various species to grow and develop under the canopy [32]. Light availability is influenced by the canopy characteristics and competing vegetation and will influence seedling growth in many years to come [33]. Thus, it is essential to understand the species-specific responses to resource availability in terms of growth and its allocation (for tree stability) and biomass production to make sound early management decisions. We established a controlled pot experiment to better understand the effects of light availability and competition type on growth and its allocation to height versus diameter and biomass production of young seedlings under different levels of light availability. We used three economically important tree species in GermanyEuropean beech, Norway spruce (Picea abies (L.) Karst.), and Douglas fir. We propose the following hypotheses:

Hypothesis H1: Relative height and diameter growth and total woody plant biomass increase with increasing light availability for all species. Depending on the shade tolerance of each species, these trends are more or less pronounced. According to the species shade tolerance, the impact of light availability is the highest for Douglas fir, followed by Norway spruce and European beech.

Hypothesis H2: Growth allocation to height increases with decreasing light availability, decreases with the increasing height achieved in the previous year, and varies depending upon the competitor's identity. According to the species shade tolerance, Douglas fir allocates more growth to height than to diameter, followed by Norway spruce and European beech. 
Hypothesis H3: Seedlings growing under interspecific competition have higher total biomass (i.e., overyielding) than seedlings growing in monospecific neighborhoods. The positive mixture effect is particularly pronounced for Douglas fir under high light availability and beech under low light availability.

In addition to the hypotheses, we present a novel way to analyze growth allocation to height versus diameter. The method can be used to assess the allometric relationship between height and diameter, assuming a simple cylindrical model for the stem of the seedlings. It is based on annual height and diameter increments, thus particularly suitable when short-term changes need to be captured, and legacy effect (e.g., from the nursery) should be excluded.

\section{Materials and Methods}

\subsection{Study Site and Experimental Setup}

We conducted a controlled shading experiment at the University of Göttingen $\left(51^{\circ} 33^{\prime} 21.6^{\prime \prime} \mathrm{N} 9^{\circ} 57^{\prime} 11.8^{\prime \prime} \mathrm{E}\right)$. The study site was located $174 \mathrm{~m}$ above sea level. According to the Köppen-Geiger climate classification, the climate in the area is temperate and oceanic. The average annual temperature is $9.2^{\circ} \mathrm{C}$, and the annual average precipitation reaches $650 \mathrm{~mm}$, of which $310 \mathrm{~mm}$ falls between May and September (www.dwd.de, accessed on 16 March 2021).

We established the experiment using three tree species-European beech (EB), Norway spruce (NS), and Douglas fir (DF). The planting material was obtained from a local nursery (Baumschule Willenbocke $\mathrm{GmbH}$, Walsrode, Germany). We used 1-yearold European beech (with an initial size of 22-56 cm), and 2-year-old Norway spruce $(10-48 \mathrm{~cm})$, and Douglas fir $(11-30 \mathrm{~cm})$ seedlings that were not undercut or transplanted.

The experiment was carried out in pots (pot dimensions: $\mathrm{H}=0.33 \mathrm{~m}, \mathrm{D}=0.56 \mathrm{~m}$, $\mathrm{V}=65 \mathrm{l}$ ). Before planting, we filled the pots with a $5 \mathrm{~cm}$ layer of coarse gravel to provide better drainage and reduce the risk of anoxic conditions due to high water saturation. Nutrient-poor sand $(0-2 \mathrm{~mm})$ was used as a potting medium. We chose sand material to help create larger pores and protect roots from hypoxia [34]. A thin fleece material was placed between the coarse gravel and the sand to prevent the sand from leaching through the coarse gravel and the drainage holes. The pots were lined on wooden laths for additional gravity drainage. An automatic dripping irrigation system was installed, and all seedlings received the same water treatment. Precipitation was able to reach the seedlings, thereby providing additional water.

Nutrients were provided using a controlled-release fertilizer (CRF) Osmocote Exact Hi.End with 12-14 months longevity (ICL SF, Nordhorn, Germany). We planted in a total of 576 pots -6 species combinations (monocultures + mixtures) $\times 3$ light treatments $\times 32$ replicates (Figure 1). The pots were organized in blocks under every light treatment. There were eight blocks of 24 pots under every light treatment. The CRF released nutrients depending on the temperature but not the irrigation regime.

We planted four seedlings per pot in both monocultures (EB, NS, DF) and mixtures of two species $(\mathrm{DF}+\mathrm{EB}, \mathrm{EB}+\mathrm{NS}, \mathrm{NS}+\mathrm{DF})$ with 16 replicates per treatment (light $\times$ composition, Figure 1 ). The planting scheme layout was square-shaped. When planted in mixtures, seedlings of the same species were planted diagonally, opposite to one another.

During the winter, the pots were arranged in groups and close to each other. The gaps between the pots were filled with hay, and each pot cluster was wrapped in a two-layer aluminum-bubble insulation foil. The following spring, the pots were re-arranged randomly within the same light-treatment levels. 


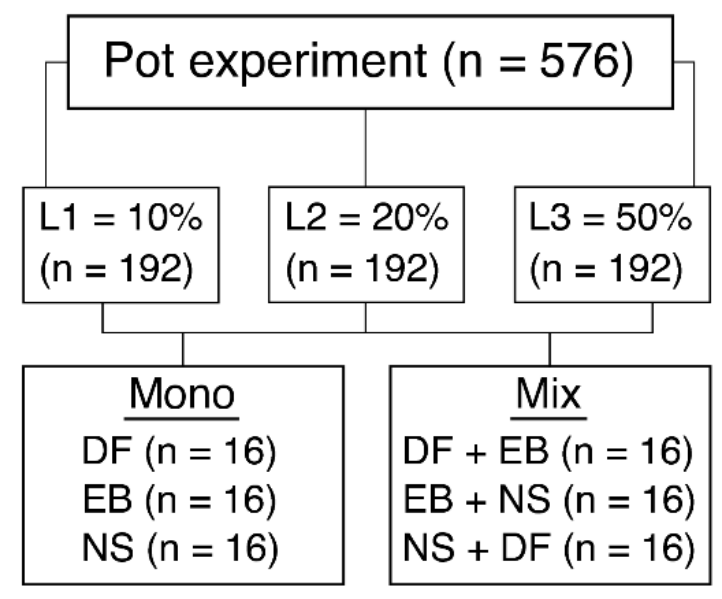

Figure 1. Experimental design. L1, L2, and L3 represent light availability levels. DF-Douglas fir, EB-European beech, NS-Norway spruce. The combinations and the number of replicates presented under the "Mono" and "Mix" categories were the same across all light levels (L1-L3).

We established three light availability levels-50\%, 20\%, and 10\%-to assess the seedlings' response to limited light availability, and determined light availability as the proportion of irradiance available under the shading nets compared to open field conditions. Irradiance was measured with an LI-COR QUANTUM ${ }^{\circledR}$ sensor (LI-COR Biosciences, Lincoln, NE, USA). The light availability levels were chosen to mimic the light conditions in gaps of varying sizes [35].

\subsection{Sampling Procedure}

We examined seedling growth over two vegetation periods (April 2018-October 2019). Seedling height and diameter ( $5 \mathrm{~cm}$ above the root collar) were measured after planting and at the end of both vegetation periods-2018 and 2019.

We carried out destructive harvesting at the end of the vegetation periods 2018 and 2019. A portion of pots was harvested in 2018 , and all the remaining pots, which still contained four living seedlings, were harvested in 2019. After the harvesting, we washed the seedlings and separated them by the compartments of leaves, branches, stems, and roots. These were dried at $70{ }^{\circ} \mathrm{C}$ for $72 \mathrm{~h}$ until a constant weight was reached. The oven-dry mass was determined to the milligram using the standard laboratory scale Sartorius MC1 LC1200S $^{\circledR}$, with an accuracy of $\pm 0.003 \mathrm{~g}$ (Sartorius AG, Göttingen, Germany).

Pots with at least one dead seedling were excluded from the study since that significantly affected the growing space and the competitive situation. Mortality (see Section 4.4) and destructive harvest in 2018 reduced the final number of pots from 576 to 202 by the end of the experiment.

\subsection{Data Processing}

The significance level for all tests was $\alpha=0.05$. All statistical analyses and tests were performed in the statistical computing software environment $R$, version 4.0.2 [36].

We determined the main competitor identity as the species of the two closest seedlings to the target seedling. For monospecific pots, the competitor's identity was identical to the target species. For mixed pots, where the seedlings of different species were planted diagonally, it was always the other species. For example, in European beech and Douglas fir mixtures, the competitor of European beech was always Douglas fir and vice versa.

\subsubsection{Relative Height and Diameter Growth}

We calculated the relative height and diameter growth to analyze the effect of light on tree growth and determine intra- and inter-specific differences along the light gradient. The relative height and diameter increment were calculated as the seasonal height or diameter increment divided by the height or diameter at the beginning of the same growing 
season/the end of the previous growing season (see absolute values used in the calculation in Table S1).

\subsubsection{Growth Allocation to Height}

The height-to-diameter ratio often describes the allometric relationship between two size-determining parameters and an individual's competitiveness under different growing conditions $[3,21]$. However, we wanted to capture the short-term effects of growing conditions and exclude the legacy of the 1-2 years that the seedlings spent in the nursery $[37,38]$. For that purpose, we assumed a simple cylindrical model for the tree stem and computed the share of the volume growth over one growing season that attributes to height growth alone (Figure 2). We called this measure the Relative Height Volume Growth $R$ and defined it as

$$
R=\frac{\Delta V_{H}}{\Delta V}=\frac{\pi \cdot\left(D_{1} / 2\right)^{2} \cdot H_{2}-\pi \cdot\left(D_{1} / 2\right)^{2} \cdot H_{1}}{\pi \cdot\left(D_{2} / 2\right)^{2} \cdot H_{2}-\pi \cdot\left(D_{1} / 2\right)^{2} \cdot H_{1}}=\frac{D_{1}^{2} \cdot\left(H_{2}-H_{1}\right)}{D_{2}^{2} \cdot H_{2}-D_{1}^{2} \cdot H_{1}}
$$

where $\Delta V_{H}$ is the volume growth due to height growth, and $\Delta V$ is the total volume growth over one growing season. Furthermore, $H_{1}$ and $H_{2}$ are the height at the beginning and the end of the growing season, and $D_{1}$ and $D_{2}$ are the diameter at the beginning and the end of the growing season. Without measurement errors, the variable $R$ should take values in the interval $[0,1]$, which is why we excluded $3.5 \%$ of the data outside this interval.
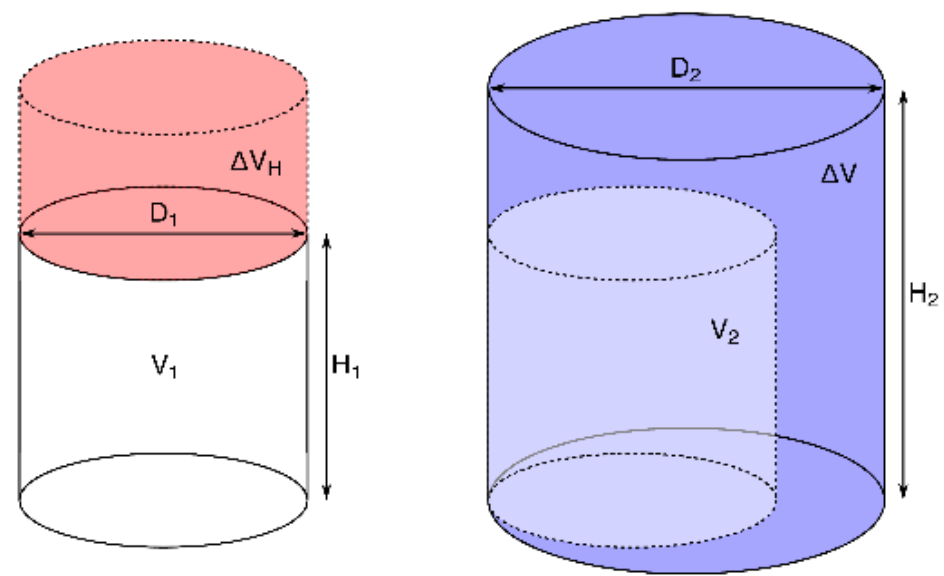

Figure 2. Visual representation of the cylindrical model for calculating the relative height volume growth $(R)$, i.e., the share of the volume growth over one growing season attributed to height growth alone. $\Delta V_{H}$ is the volume growth due to height growth, $\Delta V$ is the total volume growth over one growing season, $H_{1}$ and $H_{2}$ are the height at the beginning and the end of the growing season, and $D_{1}$ and $D_{2}$ are the diameter at the beginning and the end of the growing season.

\subsection{Statistical Analysis}

\subsubsection{Relative Height and Diameter Growth}

The Shapiro-Wilk test and a visual assessment (histograms) were used to check for potential non-normality of the relative height and diameter growth and the total biomass data. Levene's test was applied to assess the assumption of variance homogeneity. Differences in relative height and diameter growth and total biomass production were assessed with the Kruskal-Wallis non-parametric test, as the data was not normally distributed, and variance homogeneity could not be assumed. The differences were tested interspecifically, intraspecifically, and across different light levels. Whenever the differences were significant, a pairwise Wilcoxon rank-sum test with Bonferroni correction was used as a post hoc test to calculate comparisons between the groups. 


\subsubsection{Growth Allocation to Height}

To relate the relative height volume growth to explanatory variables, we used a Gaussian location-scale regression model [39], which is defined as

$$
\log \left(R_{i j t}\right)=\eta_{i j t}+\varepsilon_{i j t}, \text { where } \varepsilon_{i j t} \sim \mathcal{N}\left(0,\left(0.01+\exp \left(\zeta_{i j t}\right)\right)^{2}\right) .
$$

The response variable $R_{i j t}$ is the relative height volume growth observed for seedling $j$ in pot $i$ and year $t$. The linear predictor $\eta_{i j t}$ explains the mean of the response, while the linear predictor $\zeta i j t$ describes the standard deviation of the error term $\varepsilon_{i j t}$.

We included several fixed covariate effects and random intercepts for the pots in both predictors $\eta_{i j t}$ and $\zeta i j t$. The explanatory variables in both predictors were the species identity, the light availability, the competitor identity, the year, and the seedling height and diameter. The height and the diameter were standardized with the species and yearspecific averages. Three interactions of the species identity with the light availability, the competitor identity, and the year, were added to the mean predictor, while the predictor for the standard deviation included only one interaction between the species identity and the year.

The model was estimated with the gam (Generalized Additive Model) function and the gaulss family from the mgcv package for R [40]. We also computed the model's estimated marginal means (also known as least-square means) to compare selected covariate constellations using the emmeans package [41].

\subsubsection{Mixing Effect}

Using a quadratic linear regression model, we assessed the mixing effect on species productivity in terms of total aboveground biomass. The total aboveground biomass of the target species in mixed pots was compared to the expected productivity for a neutral mixing effect, i.e., the mean productivity of the species in monospecific pots. The mean aboveground biomass of the two compared species in pure pots was used as the fixed points of the regression curve, and the curvature was estimated through the modeling process as

$$
p_{1,2}-p_{2}-\left(p_{1}-p_{2}\right) \times m=\beta_{2}\left(m^{2}-m\right),
$$

where: $p_{1,2}$-productivity of a mixture; $p_{1}, p_{2}$-species-specific productivity; $m$-mixture proportion of species $1 ; \beta_{2}$-quadratic term.

For more detailed information, please consult Pretzsch et al. (2017) and Pretzsch et al. (2013) $[42,43]$.

\section{Results}

\subsection{Relative Height and Diameter Growth and Biomass Production}

Relative height and diameter increment increased with increasing light availability for all species (Figure 3). The only exception was European beech, for which there were no significant differences between the relative height increment under $10 \%$ and $20 \%$ light availability levels.

Relative height and diameter increment also increased with decreasing species shade tolerance across the light availability levels, i.e., European beech $<$ Norway spruce $<$ Douglas fir, (Figure 3). Relative height growth increased from $35 \pm 25 \%$ under $10 \%$ light availability to $72 \pm 40 \%$ under $50 \%$ light availability for European beech, from $32 \pm 14 \%$ to $87 \pm 38 \%$ for Norway spruce, and from $105 \pm 43 \%$ to $200 \pm 70 \%$ for Douglas fir. Relative diameter growth increased from $29 \pm 18 \%$ under $10 \%$ light availability to $53 \pm 22 \%$ under $50 \%$ light availability for European beech, from $64 \pm 35 \%$ to $134 \pm 41 \%$ for Norway spruce, and from $89 \pm 33 \%$ to $209 \pm 53 \%$ for Douglas fir.

The total aboveground woody biomass increased with increasing light availability for all the species (Figure 3). On average, the aboveground woody biomass was 2.4 times higher under $50 \%$ light availability than under 10\% light availability for European beech, 4.8 times 
higher for Norway spruce, 8.8 times higher for Douglas fir. Pronounced interspecific differences were not observed under the $10 \%$ light availability level. European beech's woody aboveground biomass was $9.4 \pm 5.5 \mathrm{~g}$, on average, and did not significantly differ from Norway spruce's $(8.4 \pm 5.3 \mathrm{~g})$ and Douglas fir's $(9.9 \pm 4.6 \mathrm{~g})$ biomass. However, the interspecific differences became more pronounced with increasing light availability. Namely, the most light-demanding species, Douglas fir, had a significantly higher woody aboveground biomass than Norway spruce and European beech under $20 \%$ and $50 \%$ light availability levels.

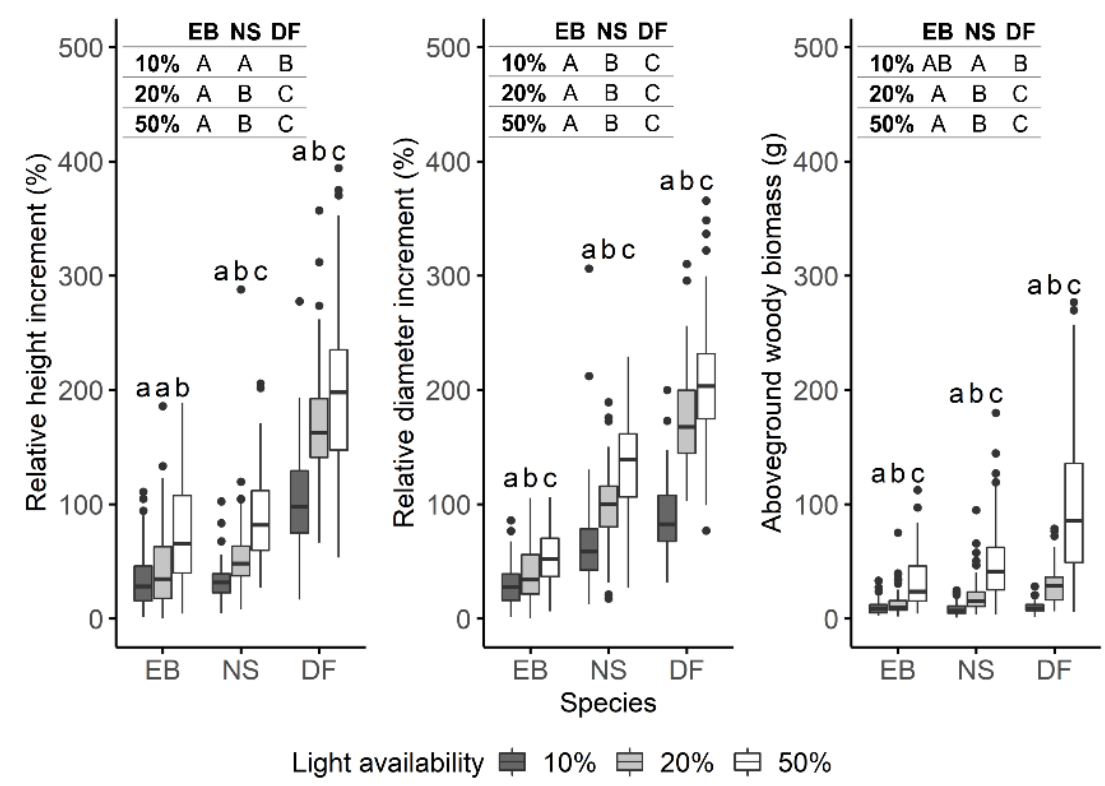

Figure 3. Relative height and diameter growth (\%) and aboveground woody biomass (g) production along the light gradient. The letters above the boxplots indicate intraspecific differences across light levels. The tables above every figure show interspecific differences between three species under different light levels. Different letters indicate significant differences $(p<0.05)$. Light availability levels range from $10-50 \%$. Species are arranged from most to least shade-tolerant $[44,45]$. Species: EB-European beech, NS-Norway spruce, DF-Douglas fir.

\subsection{Growth Allocation to Height}

All species allocated relatively more growth to height than diameter with decreasing light availability, with the strongest effect of light observed for Douglas fir (Figure 4). The predicted probability distributions of the relative height volume growth shifted to the right with decreasing light availability, indicating a negative relationship between the expected value of the relative height volume growth and light availability. The most apparent "gap" between the probability distributions for 50\% and $20 \%$ light availability was observed for Douglas fir. Another effect of decreasing light availability was the higher relative height volume growth variance, meaning that individual differences in resource allocation were more pronounced under a lower light availability.

On average, European beech invested twice as much growth to height than Douglas fir or Norway spruce (Figure 4). This pattern was true across the light levels. Under $10 \%$ and $20 \%$ light availability levels, Douglas fir's relative height volume growth was only slightly yet significantly higher than that of Norway spruce (by 2-3.5\%, on average), whereas, under $50 \%$ light availability, Norway spruce's and Douglas fir's relative higher volume growth decreased to $10 \pm 6 \%$. 


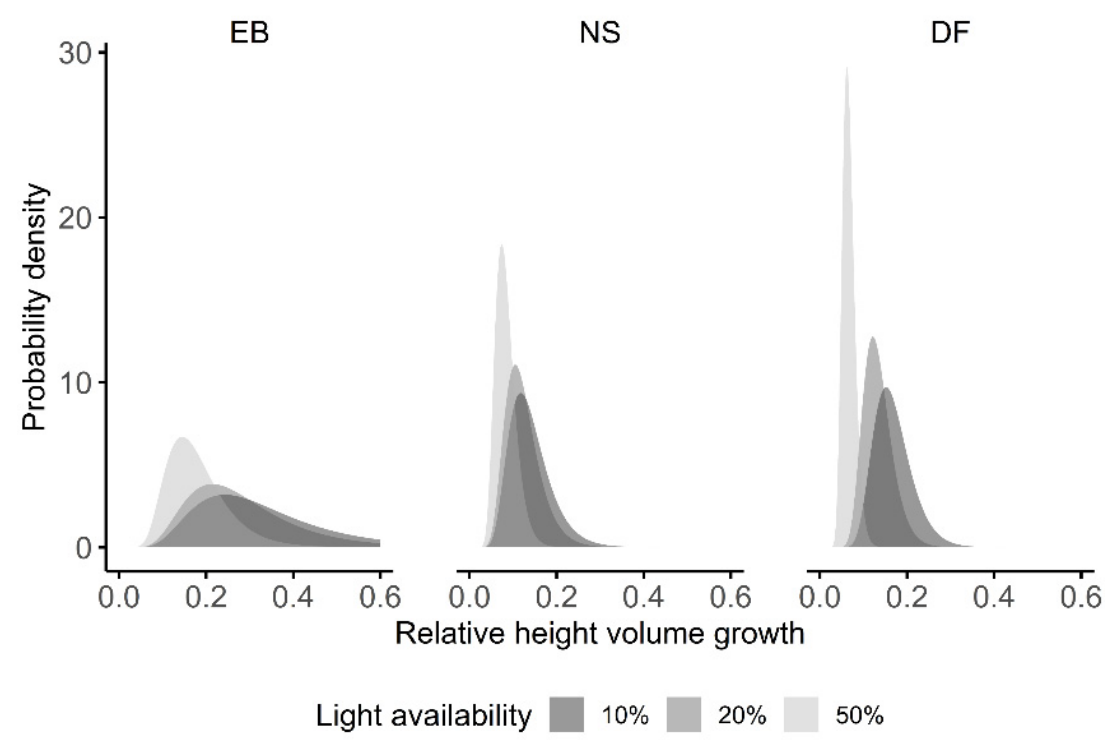

Figure 4. Predicted probability distributions of the relative height volume growth (R) for European beech (EB), Norway spruce (NS), and Douglas fir (DF) under 10\%, 20\%, and 50\% light availability levels. The predictions were based on the location-scale regression model (Equation (2)). All other covariates were fixed to a representative value.

The identity of the competing species did not have a significant effect on relative height volume growth.

The seedlings that were taller than the species average in the previous year invested less in height growth in the following year (Figure 5). In contrast, the seedlings with a greater diameter than the species average in the last year had a significantly higher relative height volume growth in the following year. This is indicated by the decrease of the predicted expected value and the predicted quantiles of the relative height volume growth ( $y$-axis) as the height (as a difference to the species average, $x$-axis) increases, meaning that taller seedlings prioritized diameter growth over height growth.

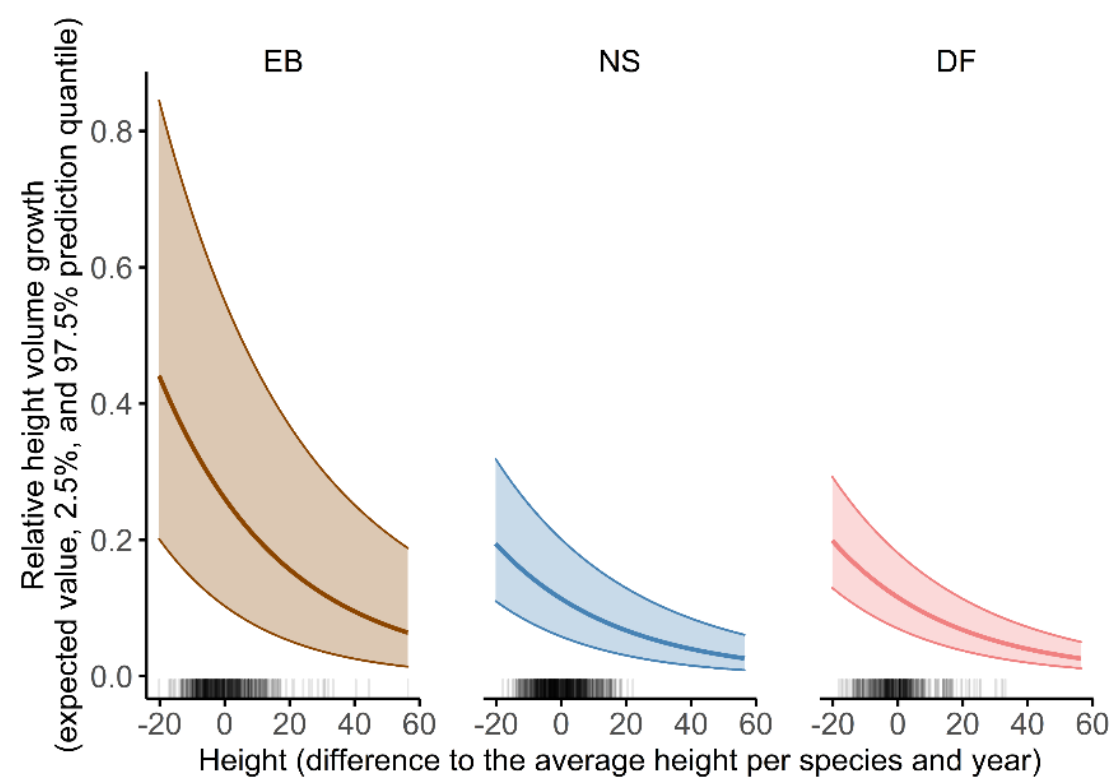

Figure 5. Predicted probability distributions (expected value, $2.5 \%$, and $97.5 \%$ quantile) of the relative height volume growth (R) of European beech (EB), Norway spruce (NS), and Douglas fir (DF) with different heights. The predictions were based on the location-scale regression model (Equation (2)). All other covariates were fixed to a representative value. 


\subsection{Mixing Effect}

We observed overall trends of positive mixing effect in mixtures of European beech with either of the conifers and the conifer mixture under 50\% light availability (Figure 6). The strongest overyielding was predicted for European beech and Douglas fir mixture under $50 \%$ light availability level, with both species predicted to have significantly higher biomass production when mixed, resulting in a significantly positive mixture effect (Figure 6A3). Decreasing light availability negatively affected Douglas fir's total aboveground biomass production, and under $10 \%$ light availability, the species were predicted to produce significantly lower biomass in mixtures than in pure pots, i.e., to underyield (Figure 6A1).

A similar pattern was observed in mixtures of Douglas fir and Norway spruce. Douglas fir was predicted to produce significantly higher biomass under $50 \%$ light availability (Figure 6C3) and underyield under 10\% light availability (Figure 6C1). However, the mixture effect on Douglas fir's biomass production did not significantly affect the overall biomass production of the mixture. Moreover, the predicted trends (not statistically significant) for the most part showed a neutral mixture effect across the light levels (Figure $6 \mathrm{C} 1, \mathrm{C} 2$ ), with a slightly positive trend under $50 \%$ light availability-primarily a result of the predicted overyielding of Douglas fir (Figure 6C3).

Significant overyielding was predicted for European beech and Norway spruce mixtures under 20\% and 50\% light availability levels (Figure 6B2,B3). Predicted overyielding under $20 \%$ light availability was mainly due to significantly higher biomass production of Norway spruce in the mixtures with European beech, whereas the overyielding under $50 \%$ light availability level could be attributed to the positive mixture effect on the biomass production of European beech when mixed with Norway spruce.

(A1)

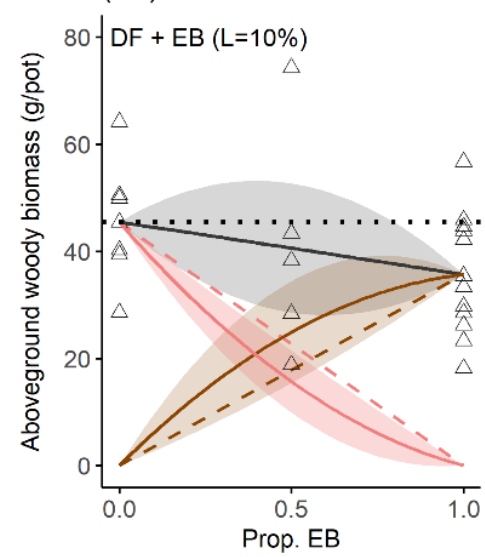

(A2)

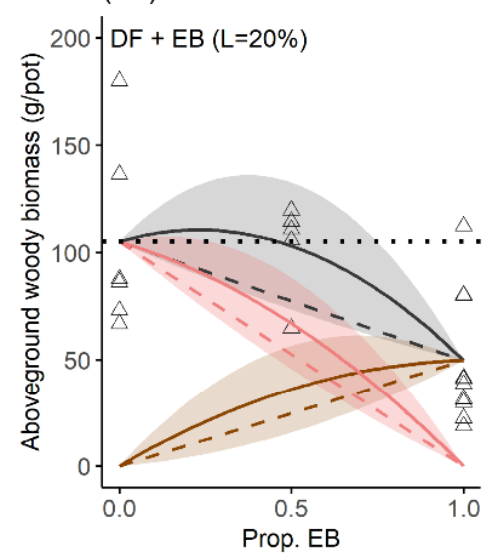

(B1)

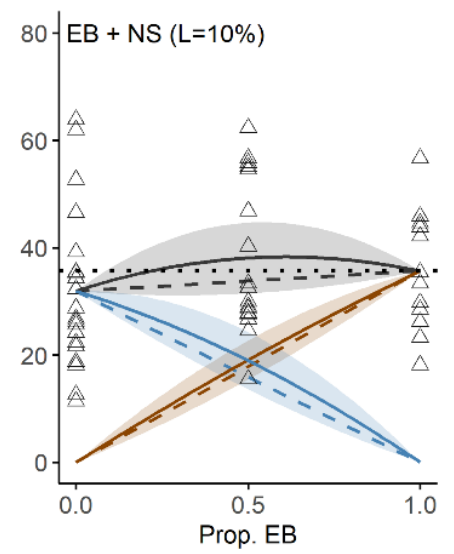

(B2)

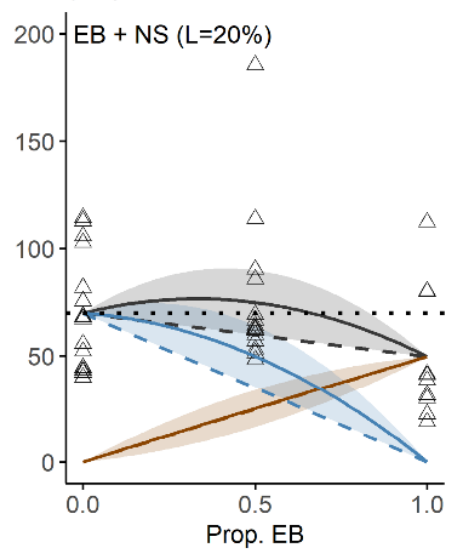

Figure 6. Cont.
(C1)

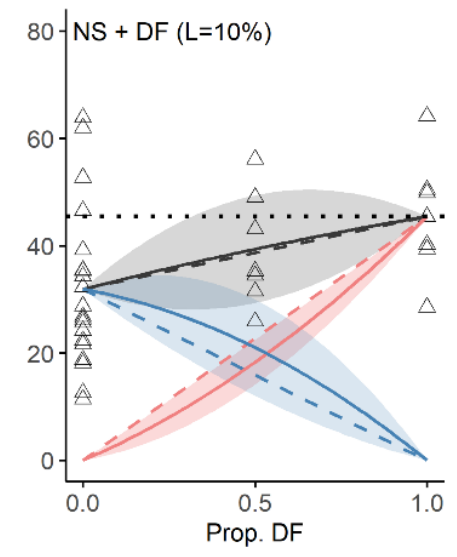

(C2)

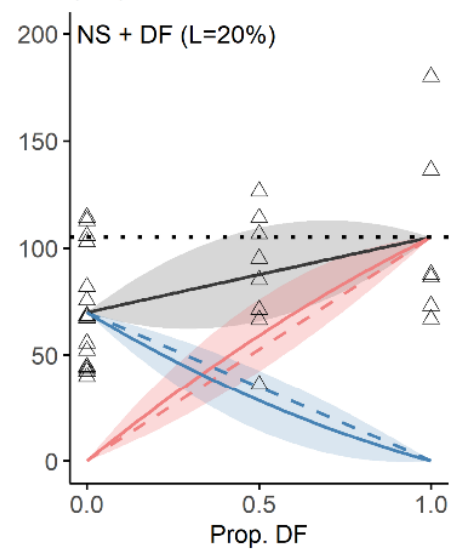


(A3)

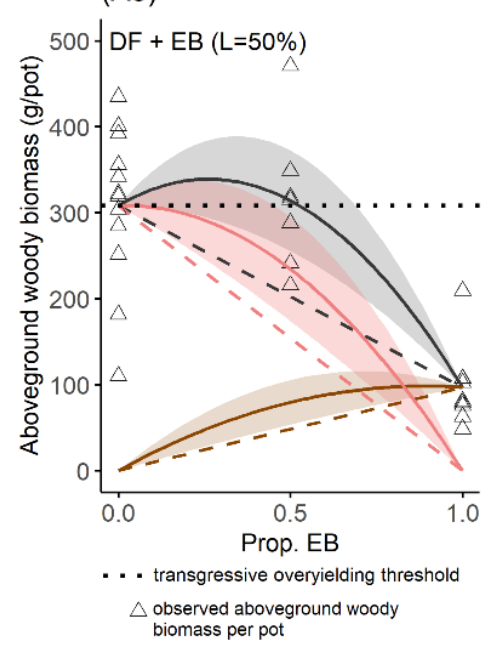

(B3)

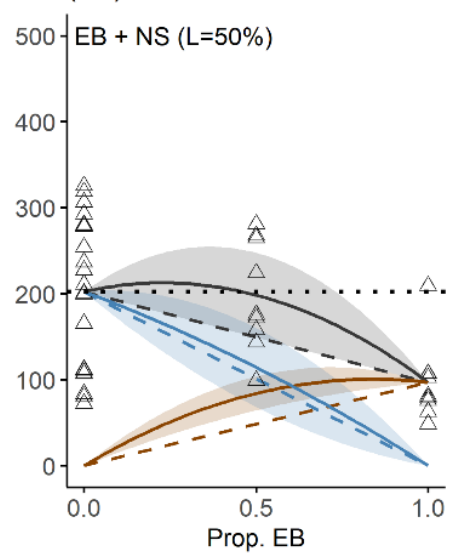

- predicted productivity of $\mathrm{EB}$ in mixture

- predicted productivity of NS in mixture

- predicted productivity of DF in mixture

_ predicted net productivity of the mixture

--- expected productivity of EB for neutral mixing effect

--- expected productivity of NS for neutral mixing effect

--- expected productivity of DF for neutral mixing effect

-- expected productivity of the mixture for neutral

mixing effect
(C3)

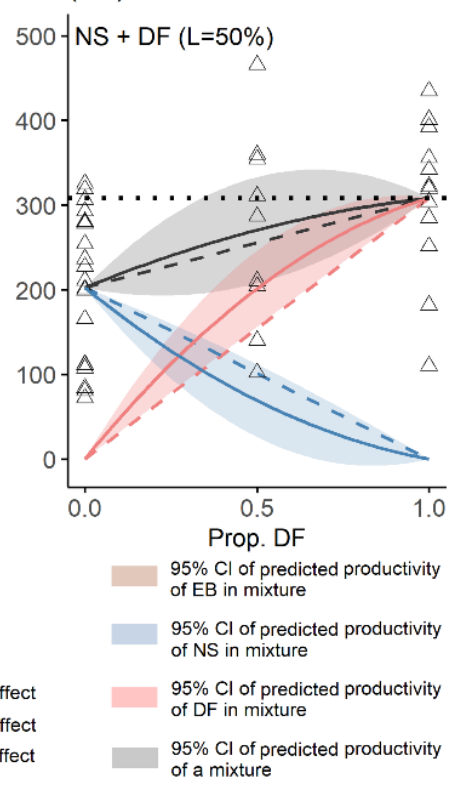

Figure 6. Cross diagrams showing the mixing effect of European beech (EB), Norway spruce (NS), and Douglas fir (DF) seedlings growing in monospecific and mixed pots under $10 \%, 20 \%$, and $50 \%$ light availability levels. The points present the observed aboveground woody biomass per pot $(\mathrm{g})$. The overyielding or underyielding effect is significant when the prediction curve's confidence bands do not overlap with the reference line. Mixed Douglas fir and European beech pots under $10 \%$ light availability level: $\mathrm{DF}+\mathrm{EB}$ ( $\mathrm{L}=10 \%$ ) (A1), mixed Douglas fir and European beech pots under $20 \%$ light availability level: DF+EB (L=20\%) (A2), mixed Douglas fir and European beech pots under 50\% light availability level: $\mathrm{DF}+\mathrm{EB}(\mathrm{L}=50 \%)(\mathrm{A} 3)$, mixed European beech and Norway spruce pots under $10 \%$ light availability level: $\mathrm{EB}+\mathrm{NS}(\mathrm{L}=10 \%)$ (B1), mixed European beech and Norway spruce pots under 20\% light availability level: EB+NS (L=20\%) (B2), mixed European beech and Norway spruce pots under 50\% light availability level: $\mathrm{EB}+\mathrm{NS}$ (L=50\%) (B3), mixed Norway spruce and Douglas fir pots under 10\% light availability level: NS+DF ( $\mathrm{L}=10 \%)(\mathrm{C} 1)$, mixed Norway spruce and Douglas fir pots under 20\% light availability level: NS+DF ( $=20 \%)($ C2), mixed Norway spruce and Douglas fir pots under 50\% light availability level: NS+DF ( $\mathrm{L}=50 \%)(\mathrm{C} 3)$.

\section{Discussion}

\subsection{Relative Height and Diameter Growth and Biomass Production}

The positive effect of light availability was reflected through increased growth and total biomass production of all species along the light gradient, as reported in other studies [8,46-50]. The light-demanding Douglas fir seedlings had higher relative height and diameter growth than the moderately shade-tolerant Norway spruce and the shadetolerant European beech seedlings, thus corroborating previous results that reported higher growth rates for light-demanding tree species both under high and low light availability levels $[7,13,51]$. Additionally, the impact of light availability decreased with increasing species' shade tolerance. The strong reaction to light by increased relative height and diameter growth of light-demanding Douglas fir indicates that the seedlings were more stressed under lower light availability levels, and that increased light availability reduced light-stress in seedlings [52].

Plants respond plastically to limited light availability by employing shade avoidance or shade tolerance strategies $[17,53,54]$. A prominent expression of the shade avoidance strategy is enhanced vertical growth to escape shade and maintain contact with the light source [50,54]. This growth strategy is associated with that of light-demanding species [55]. Shade-tolerant species generally suppress shade avoidance traits and have lower growth rates than light-demanding species in high and low resource environments $[53,56]$. 
Light-demanding species use primarily height and diameter growth, at the expense of other compartments such as branches and roots, to keep a minimum growth performance in low-resource environments [7]. This competitive strategy could explain the high competitiveness of Douglas fir seedlings in terms of relative height and diameter growth, yet lower total biomass under $10 \%$ light availability. Namely, the growth of below-ground organs is likely to be hampered, and the resources are allocated primarily to the above-ground light-capturing organs.

\subsection{Growth Allocation to Height}

All tree species increased the growth allocation to height, i.e., relative height volume growth, with decreasing light availability. Interestingly, species' identity had a more significant impact on growth allocation to height than species' shade tolerance. Specifically, European beech seedlings allocated more growth to height than the seedlings of the two conifer species, regardless of the light availability. It is likely because of the general differences in height-diameter allometry of gymnosperms and angiosperms, with gymnosperms, especially conifers, investing more in diameter growth per unit of height growth than angiosperms $[3,57]$.

We also expected that, depending on the species composition in pots, the main competitor would alter the light availability to the extent that it impacts the growth strategy of the target species, i.e., with seedlings trying to maximize the exposure to light by investing more growth to height [23]. However, we found no effect of competitors' identity on the relative height volume growth across different light availability levels. The lack of competition effect could result from a too-short time spent under the competitive situation [49], or competition occurring in the plant organs not covered in this study-branches, roots, and leaves [58].

The relationship between growth allocation to height versus diameter determines the seedlings' position and social rank [59]. Our study shows that all species' relative height volume growth decreased with increasing height gained in the previous year. This growth strategy indicates that the dominant seedlings could invest more in diameter growth (also to support the expanding crown), whereas the stressed seedlings continued to invest in height growth $[37,59]$.

\subsection{Mixing Effect}

Overyielding is a highly desirable property of mixed forests and has served as an important economic incentive for establishing mixed forests. We investigated the mixing effect across light availability levels and between competition types (monospecific vs. mixed) to determine if a positive mixture effect could be observed in the early seedling establishment phases. However, the results from the controlled experimental conditions should not necessarily be transferred to open field conditions without further considerations.

Our results on mixing effects were mainly statistically insignificant. The observed trends in aboveground biomass production depending on light availability and mixture type were in line with numerous findings from forest stands [24,25,60]. These findings emphasize the importance of species' functional dissimilarity and complementarity as the main drivers of overyielding in mixed stands. Namely, we found trends of positive mixing effect, i.e., higher biomass production in mixed than in monospecific pots, for European beech's mixtures with either of the conifers. Contrariwise, biomass production trends in mixed Douglas fir and Norway spruce pots indicated a more neutral mixing effect. On the species level, light availability positively affected the predicted biomass production of European beech and Douglas fir in mixed pots. Both species were also predicted to overyield under $50 \%$ light availability levels regardless of the mixture type. By contrast, the limited light availability (10\%) resulted in the underyielding of Douglas fir both in mixtures with European beech and Norway spruce.

Species complementarity can be expressed through growth facilitation and competitive reduction (interspecific competition < intraspecific competition) $[27,61]$. Therefore, 
functionally dissimilar species, i.e., species with different phyletic affiliation, shade tolerance, rooting depth, and leaf phenology, are likely to use resources more complementary, resulting in a positive mixture effect and higher biomass production [25,62]. However, competition reduction and facilitation lead to higher biomass production and growth only if the resource uptake is improved; otherwise, the positive effect can be masked by the increased use of the resource by the species that benefited from the competition reduction the most $[60,63]$.

\subsection{The Experimental Design}

The experimental design of the current study was created to analyze the effects of light and nutrient availability, species identity, competition type, and interactions of these factors on selected tree growth parameters and biomass production of planted seedlings. However, similar to many other pot experiments, our research suffers from several limitations such as (i) short duration of the experiment (two vegetation periods), (ii) limited above- and belowground growing space in the later stages of the experiment, and (iii) the potential effect of shading nets on light quality $[11,34,64,65]$. Additionally, our experiment was negatively impacted by the high mortality of seedlings and failed nutrient treatment.

Seedling mortality: Factors such as planting shock and aphid infestation influenced the survival and vitality of the studied species. Many Douglas fir seedlings were lost shortly after planting, which significantly reduced the number of replicates for pure Douglas fir pots and pots where Douglas fir was mixed with European beech and Norway spruce. Douglas fir seedlings have been previously reported to be prone to transplanting shock [66]. Growing seedlings from seeds or cuttings can significantly increase the survival rates and yield seedlings that are better adapted to the experimental conditions than seedlings from a nursery [65].

A severe woolen aphid (Phyllaphis fagi L.) infestation impacted European beech seedlings' health and vigor. In the first year of the study, the infestation was contained. However, in the second year of the experiment, many beach seedlings experienced rapid dieback in the late spring, which was presumably caused by the same aphids' infestation. The infestation significantly reduced the number of usable replicates. Norway spruce seedlings experienced a brown spruce shoot aphid (Cinara pilicornis Hartig) infestation, but most seedlings recovered after insecticide Spruzit AF Schädlingsfrei (Neudorff GmbH, Emmerthal, Germany) applications. Aphid infestations are widespread in conditions where constant air exchange is limited, such as in nursery greenhouses or our experiment where the shading nets blocked some of the airflow [67].

Fertilizer treatment: Initially, the experiment was established with two levels of fertilizer treatment. Half of the pots received light treatment (2 g CRF per liter of the substrate) and the other half received heavy treatment ( $5 \mathrm{~g}$ CRF per liter of the substrate). Temperature is one of the main factors affecting CRF's nutrient release [68], and the first summer of the experiment (2018) was extremely hot, with 20 days above $30{ }^{\circ} \mathrm{C}$ (http:/ / www.wetterstation-goettingen.de/, accessed on 16 March 2021). The heat caused the fertilizer to break down uncontrollably and significantly impact the nutrient treatment quality. The fertilizer leached into the pots and had to be washed out since the trees could not take up water. After the CRF's breakdown, we did not see an effect of the different fertilizer treatment levels in the preliminary analysis; thus, it was excluded from further analysis. At the same time, seedlings did not show any significant signs of lack of nutrients, like discolored or curled leaves, burnt leaf tips, terminal bud die-off [69]. Therefore, repeated fertilizer application was not carried the second time, but seedlings were closely monitored for the signs of nutrient deficiency. It has to be considered that the given fertilizer treatment might have benefited some species more than others and changed the competitive ability for some species, for example, if comparing the studied species, the growth of Norway spruce has been reported to be impacted by the nutrient availability more than European beech or Douglas fir [21,48]. 
Against this background, we suggest considering the discussed limitations when interpreting and generalizing the results.

\section{Conclusions}

Understanding the growth strategy of seedlings grown under different light availability levels and competition types can be crucial for early forest regeneration and management decisions. Our study confirmed that more light-demanding seedlings react stronger to increased light availability while retaining high growth rates in lower light availability levels as a shade avoidance strategy.

We devised a new solution to analyze relative growth allocation to height versus diameter by assuming a tree stem's simple cylindric model. We confirmed general differences in growth allocation strategies between angiosperms and gymnosperms, with angiosperms investing more in height growth and gymnosperms-in diameter growth. We also found that trees allocated relatively more growth to height with decreasing light availability and that the height from the previous year determined growth allocation in the following year. As a result, if the seedlings have enough growth resources available to expand their crowns, they can begin investing more growth to diameter to gain mechanical support.

Higher species functional dissimilarity (gymnosperms vs. angiosperms) and sufficient light availability were the main drivers of positive mixture effect trends, i.e., higher biomass production in mixed than monospecific pots.

Our study emphasized the importance of light availability for growth and biomass production of economically desirable European beech, Norway spruce, and Douglas fir species under controlled experimental conditions (ex situ). Further research on how the desired state is achieved in situ by managing mixed-species regenerations with controlling canopy density is critical for areas where close-to-nature forestry and a strong preference for mixed-species forests (at the stand-level) prevail.

Supplementary Materials: The following are available online at https:/ /www.mdpi.com/article/10

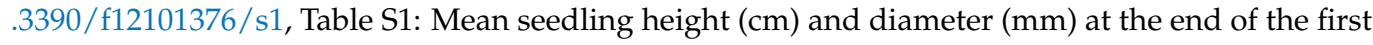
(2018) and second (2019) growing season and total seedling biomass (g).

Author Contributions: I.B. and P.A. designed the study. P.A. supervised the study. I.B. carried out the implementation and collected the data. I.B. and H.R. performed the data analysis. H.R. contributed code and tools for the statistical models. I.B. wrote the manuscript. All authors provided critical input and feedback and helped shape the research, analysis, and manuscript. All authors have read and agreed to the published version of the manuscript.

Funding: The work of Ieva Bebre and Hannes Riebl on this article was funded by the German Research Foundation (DFG) through the Research Training Group 2300: Enrichment of European Beech Forests with Conifers (316045089/GRK2300).

Institutional Review Board Statement: Not applicable.

Informed Consent Statement: Not applicable.

Data Availability Statement: The datasets generated during the current study are available from PANGAEA ${ }^{\circledR}$ Data Publisher (https://doi.pangaea.de/10.1594/PANGAEA.933150, accessed on 11 August 2021). The code is available from the corresponding author on reasonable request.

Acknowledgments: We acknowledge support by the Open Access Publication Funds of the University of Göttingen. We thank the technicians, Michael Unger, Karl-Heinz Heine, Andreas Parth, Ulrike Westphal, and Julian Meyer, of the Department of Silviculture and Forest Ecology of the Temperate Zones, University of Göttingen and the student assistants for their help with maintenance, sampling, and data collection.

Conflicts of Interest: The authors declare no conflict of interest. The funders had no role in the design of the study, in the collection, analyses, or interpretation of data, in the writing of the manuscript, or in the decision to publish the results. 


\section{References}

1. Pacala, S.W.; Canham, C.D.; Silander, J.A., Jr.; Kobe, R.K. Sapling Growth as a Function of Resources in a North Temperate Forest. Can. J. For. Res. 1994, 24, 2172-2183. [CrossRef]

2. Claveau, Y.; Messier, C.; Comeau, P.G.; Coates, K.D. Growth and Crown Morphological Responses of Boreal Conifer Seedlings and Saplings with Contrasting Shade Tolerance to a Gradient of Light and Height. Can. J. For. Res. 2002, 32, 458-468. [CrossRef]

3. Hulshof, C.M.; Swenson, N.G.; Weiser, M.D. Tree Height-Diameter Allometry across the United States. Ecol. Evol. 2015, 5, 1193-1204. [CrossRef]

4. Weiner, J. Asymmetric Competition in Plant Populations. Trends Ecol. Evol. 1990, 5, 360-364. [CrossRef]

5. Bauer, S.; Wyszomirski, T.; Berger, U.; Hildenbrandt, H.; Grimm, V. Asymmetric Competition as a Natural Outcome of Neighbour Interactions among Plants: Results from the Field-of-Neighbourhood Modelling Approach. Plant Ecol. 2004, 170, $135-145$. [CrossRef]

6. Schwinning, S.; Weiner, J. Mechanisms Determining the Degree of Size Asymmetry in Competition among Plants. Oecologia 1998, 113, 447-455. [CrossRef]

7. Chen, H. Interspecific Responses of Planted Seedlings to Light Availability in Interior British Columbia: Survival, Growth, Allometric Patterns, and Specific Leaf Area. Can. J. For. Res. 1997, 27, 1383-1393. [CrossRef]

8. Lilles, E.B.; Astrup, R. Multiple Resource Limitation and Ontogeny Combined: A Growth Rate Comparison of Three Co-Occurring Conifers. Can. J. For. Res. 2012, 42, 99-110. [CrossRef]

9. Wright, E.F.; Coates, K.D.; Canham, C.D.; Bartemucci, P. Species Variability in Growth Response to Light across Climatic Regions in Northwestern British Columbia. Can. J. For. Res. 1998, 28, 871-886. [CrossRef]

10. Craine, J.M.; Dybzinski, R. Mechanisms of Plant Competition for Nutrients, Water and Light. Funct. Ecol. 2013, 27, 833-840. [CrossRef]

11. Aerts, R.; Boot, R.G.A.; van der Aart, P.J.M. The Relation between Above- and Belowground Biomass Allocation Patterns and Competitive Ability. Oecologia 1991, 87, 551-559. [CrossRef]

12. Poorter, L. Growth Responses of 15 Rain-Forest Tree Species to a Light Gradient: The Relative Importance of Morphological and Physiological Traits. Funct. Ecol. 1999, 13, 396-410. [CrossRef]

13. Zavala, M.A.; Espelta, J.M.; Caspersen, J.; Retana, J. Interspecific Differences in Sapling Performance with Respect to Light and Aridity Gradients in Mediterranean Pine-Oak Forests: Implications for Species Coexistence. Can. J. For. Res. 2011, 41, 1432-1444. [CrossRef]

14. Annighöfer, P.; Petritan, A.M.; Petritan, I.C.; Ammer, C. Disentangling Juvenile Growth Strategies of Three Shade-Tolerant Temperate Forest Tree Species Responding to a Light Gradient. For. Ecol. Manag. 2017, 391, 115-126. [CrossRef]

15. Walters, M.B.; Reich, P.B. Are Shade Tolerance, Survival, and Growth Linked? Low Light and Nitrogen Effects on Hardwood Seedlings. Ecology 1996, 77, 841-853. [CrossRef]

16. Prasad, M.N.W. (Ed.) Plant Ecophysiology; John Wiley \& Sons: New York, NY, USA, 1997; ISBN 978-0-471-13157-1.

17. Valladares, F.; Niinemets, Ü. Shade Tolerance, a Key Plant Feature of Complex Nature and Consequences. Annu. Rev. Ecol. Evol. Syst. 2008, 39, 237-257. [CrossRef]

18. Sumida, A.; Ito, H.; Isagi, Y. Trade-off between Height Growth and Stem Diameter Growth for an Evergreen Oak, Quercus Glauca, in a Mixed Hardwood Forest. Funct. Ecol. 1997, 11, 300-309. [CrossRef]

19. Lines, E.R.; Zavala, M.A.; Purves, D.W.; Coomes, D.A. Predictable Changes in Aboveground Allometry of Trees along Gradients of Temperature, Aridity and Competition. Glob. Ecol. Biogeogr. 2012, 21, 1017-1028. [CrossRef]

20. Becker, P. Competition in the Regeneration Niche between Conifers and Angiosperms: Bond's Slow Seedling Hypothesis. Funct. Ecol. 2000, 14, 401-412. [CrossRef]

21. Amoroso, M.M.; Turnblom, E.C. Comparing Productivity of Pure and Mixed Douglas-Fir and Western Hemlock Plantations in the Pacific Northwest. Can. J. For. Res. 2006, 36, 1484-1496. [CrossRef]

22. King, D.A. Tree Allometry, Leaf Size and Adult Tree Size in Old-Growth Forests of Western Oregon. Tree Physiol. $1991,9,369-381$. [CrossRef]

23. Henry, H.A.L.; Aarssen, L.W. The Interpretation of Stem Diameter-Height Allometry in Trees: Biomechanical Constraints, Neighbour Effects, or Biased Regressions? Ecol. Lett. 1999, 2, 89-97. [CrossRef]

24. Del Río, M.; Condés, S.; Pretzsch, H. Analyzing Size-Symmetric vs. Size-Asymmetric and Intra- vs. Inter-Specific Competition in Beech (Fagus sylvatica L.) Mixed Stands. For. Ecol. Manag. 2014, 325, 90-98. [CrossRef]

25. Lu, H.; Mohren, G.M.J.; den Ouden, J.; Goudiaby, V.; Sterck, F.J. Overyielding of Temperate Mixed Forests Occurs in EvergreenDeciduous but Not in Deciduous-Deciduous Species Mixtures over Time in the Netherlands. For. Ecol. Manag. 2016, 376, 321-332. [CrossRef]

26. Fichtner, A.; Härdtle, W.; Bruelheide, H.; Kunz, M.; Li, Y.; von Oheimb, G. Neighbourhood Interactions Drive Overyielding in Mixed-Species Tree Communities. Nat. Commun. 2018, 9, 1144. [CrossRef]

27. Pretzsch, H.; Block, J.; Dieler, J.; Dong, P.H.; Kohnle, U.; Nagel, J.; Spellmann, H.; Zingg, A. Comparison between the Productivity of Pure and Mixed Stands of Norway Spruce and European Beech along an Ecological Gradient. Ann. For. Sci. 2010, 67, 712. [CrossRef]

28. Pretzsch, H.; Schütze, G. Effect of Tree Species Mixing on the Size Structure, Density, and Yield of Forest Stands. Eur. J. For. Res. 2016, 135, 1-22. [CrossRef] 
29. Radosevich, S.R.; Hibbs, D.E.; Ghersa, C.M. Effects of Species Mixtures on Growth and Stand Development of Douglas-Fir and Red Alder. Can. J. For. Res. 2006, 36, 768-782. [CrossRef]

30. Thurm, E.A.; Pretzsch, H. Improved Productivity and Modified Tree Morphology of Mixed versus Pure Stands of European Beech (Fagus Sylvatica) and Douglas-Fir (Pseudotsuga Menziesii) with Increasing Precipitation and Age. Ann. For. Sci. 2016, 73, 1047-1061. [CrossRef]

31. Borrass, L.; Kleinschmit, D.; Winkel, G. The "German Model” of Integrative Multifunctional Forest Management-Analysing the Emergence and Political Evolution of a Forest Management Concept. For. Policy Econ. 2017, 77, 16-23. [CrossRef]

32. Bertin, S.; Palmroth, S.; Kim, H.S.; Perks, M.P.; Mencuccini, M.; Oren, R. Modelling Understorey Light for Seedling Regeneration in Continuous Cover Forestry Canopies. Forestry 2011, 84, 397-409. [CrossRef]

33. Montoro Girona, M.; Lussier, J.-M.; Morin, H.; Thiffault, N. Conifer Regeneration After Experimental Shelterwood and Seed-Tree Treatments in Boreal Forests: Finding Silvicultural Alternatives. Front. Plant Sci. 2018, 9, 1145. [CrossRef] [PubMed]

34. Passioura, J.B. Viewpoint: The Perils of Pot Experiments. Funct. Plant Biol. 2006, 33, 1075. [CrossRef]

35. Gálhidy, L.; Mihók, B.; Hagyó, A.; Rajkai, K.; Standovár, T. Effects of Gap Size and Associated Changes in Light and Soil Moisture on the Understorey Vegetation of a Hungarian Beech Forest. Plant Ecol. 2006, 183, 133-145. [CrossRef]

36. R Core Team. R: A Language and Environment for Statistical Computing; R Foundation for Statistical Computing: Vienna, Austria, 2020.

37. Trouvé, R.; Bontemps, J.-D.; Collet, C.; Seynave, I.; Lebourgeois, F. Growth Partitioning in Forest Stands Is Affected by Stand Density and Summer Drought in Sessile Oak and Douglas-Fir. For. Ecol. Manag. 2014, 334, 358-368. [CrossRef]

38. Noyer, E.; Ningre, F.; Dlouhá, J.; Fournier, M.; Collet, C. Time Shifts in Height and Diameter Growth Allocation in Understory European Beech (Fagus sylvatica L.) Following Canopy Release. Trees 2019, 33, 333-344. [CrossRef]

39. Rigby, R.A.; Stasinopoulos, D.M. Generalized Additive Models for Location, Scale and Shape (with Discussion). J. R. Stat. Soc. Ser. C 2005, 54, 507-554. [CrossRef]

40. Wood, S.N. Fast Stable Restricted Maximum Likelihood and Marginal Likelihood Estimation of Semiparametric Generalized Linear Models. J. R. Stat. Soc. Ser. B 2011, 73, 3-36. [CrossRef]

41. Lenth, R. Emmeans: Estimated Marginal Means, Aka Least-Squares Means; R Package Version 1.5.4; R Foundation for Statistical Computing: Vienna, Austria, 2020.

42. Pretzsch, H.; Forrester, D.I.; Bauhus, J. Mixed-Species Forests; Springer: Berlin/Heidelberg, Germany, 2017; ISBN 978-3-662-54551-5.

43. Pretzsch, H.; Bielak, K.; Block, J.; Bruchwald, A.; Dieler, J.; Ehrhart, H.-P.; Kohnle, U.; Nagel, J.; Spellmann, H.; Zasada, M.; et al. Productivity of Mixed versus Pure Stands of Oak (Quercus petraea (Matt.) Liebl. and Quercus robur L.) and European Beech (Fagus sylvatica L.) along an Ecological Gradient. Eur. J. For. Res. 2013, 132, 263-280. [CrossRef]

44. Baker, F.S. A Revised Tolerance Table. J. For. 1949, 47, 179-181.

45. Ellenberg, H.; Leuschner, C. Vegetation Mitteleuropas Mit Den. Alpen: In Ökologischer, Dynamischer Und Historischer Sicht; UTB Botanik, Ökologie, Agrar- und Forstwissenschaften, Geographie; 6. Auflage; Verlag Eugen Ulmer: Stuttgart, Germany, 2010; ISBN 978-3-8252-8104-5.

46. Kunstler, G.; Curt, T.; Bouchaud, M.; Lepart, J. Growth, Mortality, and Morphological Response of European Beech and Downy Oak along a Light Gradient in Sub-Mediterranean Forest. Can. J. For. Res. 2005, 35, 1657-1668. [CrossRef]

47. Petriţan, A.M.; von Lüpke, B.; Petriţan, I.C. Influence of Light Availability on Growth, Leaf Morphology and Plant Architecture of Beech (Fagus sylvatica L.), Maple (Acer pseudoplatanus L.) and Ash (Fraxinus excelsior L.) Saplings. Eur. J. For. Res. 2009, 128, 61-74. [CrossRef]

48. Schall, P.; Lödige, C.; Beck, M.; Ammer, C. Biomass Allocation to Roots and Shoots Is More Sensitive to Shade and Drought in European Beech than in Norway Spruce Seedlings. For. Ecol. Manag. 2012, 266, 246-253. [CrossRef]

49. Sevillano, I.; Short, I.; Grant, J.; O’Reilly, C. Effects of Light Availability on Morphology, Growth and Biomass Allocation of Fagus Sylvatica and Quercus Robur Seedlings. For. Ecol. Manag. 2016, 374, 11-19. [CrossRef]

50. Annighöfer, P.; Seidel, D.; Ammer, C.; Stephens, S.L.; York, R.A. Silvicultural Implications from Analyzing Light Induced Height Growth Development of Eight North American Juvenile Tree Species in Mixed-Conifer Forests. Forestry 2019, 92, 616-626. [CrossRef]

51. Kitajima, K. Relative Importance of Photosynthetic Traits and Allocation Patterns as Correlates of Seedling Shade Tolerance of 13 Tropical Trees. Oecologia 1994, 98, 419-428. [CrossRef]

52. Annighöfer, P. Stress Relief through Gap Creation? Growth Response of a Shade Tolerant Species (Fagus sylvatica L.) to a Changed Light Environment. For. Ecol. Manag. 2018, 415-416, 139-147. [CrossRef]

53. Gommers, C.M.M.; Visser, E.J.W.; Onge, K.R.S.; Voesenek, L.A.C.J.; Pierik, R. Shade Tolerance: When Growing Tall Is Not an Option. Trends Plant Sci. 2013, 18, 65-71. [CrossRef]

54. Gruntman, M.; Groß, D.; Májeková, M.; Tielbörger, K. Decision-Making in Plants under Competition. Nat. Commun. 2017, 8, 2235. [CrossRef] [PubMed]

55. Beaudet, M.; Messier, C. Growth and Morphological Responses of Yellow Birch, Sugar Maple, and Beech Seedlings Growing under a Natural Light Gradient. Can. J. For. Res. 1998, 28, 1007-1015. [CrossRef]

56. Reich, P.B.; Tjoelker, M.G.; Walters, M.B.; Vanderklein, D.W.; Buschena, C. Close Association of RGR, Leaf and Root Morphology, Seed Mass and Shade Tolerance in Seedlings of Nine Boreal Tree Species Grown in High and Low Light. Funct. Ecol. 1998, 12, 327-338. [CrossRef] 
57. Niklas, K.J. Plant. Allometry: The Scaling of Form. and Process; University of Chicago Press: Chicago, IL, USA, 1994; ISBN 978-0-22658081-4.

58. Poorter, H.; Niklas, K.J.; Reich, P.B.; Oleksyn, J.; Poot, P.; Mommer, L. Biomass Allocation to Leaves, Stems and Roots: MetaAnalyses of Interspecific Variation and Environmental Control: Tansley Review. New Phytol. 2012, 193, 30-50. [CrossRef] [PubMed]

59. Poorter, L.; Bongers, L.; Bongers, F. Architecture Of 54 Moist-Forest Tree Species: Traits, Trade-Offs, and Functional Growth. Ecology 2006, 87, 1289-1301. [CrossRef]

60. Ammer, C. Diversity and Forest Productivity in a Changing Climate. New Phytol. 2019, 221, 50-66. [CrossRef]

61. Forrester, D.I.; Albrecht, A.T. Light Absorption and Light-Use Efficiency in Mixtures of Abies Alba and Picea Abies along a Productivity Gradient. For. Ecol. Manag. 2014, 328, 94-102. [CrossRef]

62. Madrigal-González, J.; Ruiz-Benito, P.; Ratcliffe, S.; Calatayud, J.; Kändler, G.; Lehtonen, A.; Dahlgren, J.; Wirth, C.; Zavala, M.A. Complementarity Effects on Tree Growth Are Contingent on Tree Size and Climatic Conditions across Europe. Sci. Rep. 2016, 6, 32233. [CrossRef]

63. Forrester, D.I.; Bauhus, J. A Review of Processes Behind Diversity—Productivity Relationships in Forests. Curr. For. Rep. 2016, 2, 45-61. [CrossRef]

64. Poorter, H.; Bühler, J.; van Dusschoten, D.; Climent, J.; Postma, J.A. Pot Size Matters: A Meta-Analysis of the Effects of Rooting Volume on Plant Growth. Funct. Plant Biol. 2012, 39, 839. [CrossRef]

65. Kawaletz, H.; Mölder, I.; Annighöfer, P.; Terwei, A.; Zerbe, S.; Ammer, C. Pot Experiments with Woody Species-A Review. Forestry 2014, 87, 482-491. [CrossRef]

66. Haase, L.D.; Robin, R. Soil Moisture Stress Induces Transplant Shock in Stored and Unstored 2+0 Douglas-Fir Seedlings of Varying Root Volumes. For. Sci. 1993, 39, 275-294. [CrossRef]

67. Iversen, T.; Harding, S. Biological and Other Alternative Control Methods against the Woolly Beech Aphid Phyllaphis Fagi L. on Beech Fagus Sylvatica Seedlings in Forest Nurseries. J. Pest. Sci. 2007, 80, 159-166. [CrossRef]

68. Adams, C.; Frantz, J.; Bugbee, B. Macro- and Micronutrient-Release Characteristics of Three Polymer-Coated Fertilizers: Theory and Measurements. J. Plant Nutr. Soil Sci. 2013, 176, 76-88. [CrossRef]

69. Hacskaylo, J.; Finn, R.F.; Vimmerstedt, J.P. Deficiency Symptoms of Some Forest Trees; Ohio Agricultural Research and Development Center: Wooster, OH, USA, 1969; p. 68. 